\title{
Faktor risiko obesitas pada ibu rumah tangga miskin
}

\section{Obesity risk factors among poor housewives}

\author{
Digna Niken Purwaningrum¹, Hamam Hadi², I Made Alit Gunawan ${ }^{3}$
}

\begin{abstract}
Background: Food insecurity was associated with allocation of income for consumption of energy-dense foods that may cause obesity amongst poor family. In addition, low physical activity may lead to obesity, particularly among individual living in disadvantaged situation.

Objective: To identify the risk factors of obesity among poor housewives in Yogyakarta.

Method: This was a case control study, case group was obese housewives and the control group was non obese housewives. The locations of the study were Bumijo and Pringgokusuman which have high population density. The samples were taken purposively. Each groups consisted of 70 housewives (1:1) and were matched according to age. Mc.Nemar test and conditional logistic regression were used to identify the risk factors of obesity.

Results: There were no significant differences in characteristics between the two groups. Food insecurity reached $91,43 \%$ in the control group, while the proportion of excessive energy intake in the case group was higher than in control group (37.86\% Vs 24.29\%). Excessive fat intake in the case group was found in $30 \%$ subjects, compared to $28.57 \%$ in the control group. Low physical activity was found in $40 \%$ of subjects in the case group, and $10 \%$ of subjects in the control group. The result of Mc.Nemar test showed that food insecurity, energy and fat intake were not significantly associated with obesity $(p>0.05)$. While physical activity was associated with obesity $(p=0.0001)$. The result of conditional logistic regression revealed that physical activity was the dominant risk factor for obesity among poor housewives $\left(R^{2}=0.1916\right)$.

Conclusion: Food security status was not a risk factor for obesity among poor housewives. Energy intake and fat intake contributed to the prevalence of obesity though the influence was weaker than physical activity.
\end{abstract}

KEY WORDS: risk factor, obesity, poor housewives, physical activity

\begin{abstract}
ABSTRAK
Latar belakang: Status rawan pangan berhubungan dengan alokasi penggunaan pendapatan pada konsumsi pangan yang tinggi energi yang kemungkinan dapat menyebabkan obesitas. Selain ketahanan pangan dan faktor asupan makanan, aktivitas fisik diduga berperan sebagai faktor risiko obesitas, terlebih pada individu yang tinggal di tempat yang kurang menguntungkan di perkotaan.

Tujuan: Mengetahui faktor risiko terjadinya obesitas pada ibu rumah tangga miskin di Kota Yogyakarta.

Metode: Penelitian ini merupakan penelitian kasus kontrol. Kasus adalah ibu rumah tangga miskin yang mengalami obesitas, kontrol adalah ibu rumah tangga miskin yang tidak mengalami obesitas. Lokasi penelitian di Kelurahan Bumijo dan Pringgokusuman, Kota Yogyakarta. Penentuan sampel menggunakan metode purposive sampling dengan menentukan kriteria inklusi dan eksklusi. Jumlah sampel pada kasus 70 orang dan kontrol 70 orang (1:1) dengan matching pada umur. Uji statistic Mc.Nemar dan conditional logistic regression dilakukan untuk mengidentifikasi variabel yang merupakan faktor risiko.

Hasil: Tidak ditemukan perbedaan karakteristik antara kedua kelompok. Status rawan pangan lebih banyak terjadi pada kelompok kontrol (91,43\%) dan proporsi asupan energi berlebih pada kelompok kasus mencapai 37,86\%, lebih tinggi dari kelompok kontrol (24,29\%). Asupan lemak berlebih pada kelompok kasus mencapai 30\% sedangkan pada kelompok kontrol mencapai 28,57\%. Aktivitas fisik yang rendah mencapai $40 \%$ pada kelompok kasus sedangkan pada kelompok kontrol mencapai 10\%. Uji Mc.Nemar menunjukkan status ketahanan pangan, asupan energi, dan asupan lemak tidak berhubungan bermakna dengan obesitas $(p>0,05 ; O R=0,67 ; 1,5 ; 1,1)$. Aktivitas fisik berhubungan dengan obesitas ( $p=0,000 ; O R=8)$. Uji conditional logistic regression menunjukkan aktivitas fisik merupakan faktor risiko dominan terhadap terjadinya obesitas $\left(R^{2}=0,1916\right)$.

Kesimpulan: Status ketahanan pangan bukan merupakan faktor risiko obesitas pada ibu rumah tangga miskin di Yogyakarta. Asupan energi dan lemak memberikan kontribusi terhadap terjadinya obesitas walaupun pengaruhnya lebih kecil dibandingkan aktivitas fisik.
\end{abstract}

KATA KUNCI: faktor risiko, obesitas, ibu rumah tangga miskin, aktivitas fisik

\footnotetext{
${ }^{1}$ Korespondensi: Pusat Kebijakan dan Manajemen Kesehatan (PKMK), Fakultas Kedokteran Universitas Gadjah Mada, Gd. IKM Baru Lt.2 (Sayap Utara), Jl. Farmako Sekip Utara, Yogyakarta 55281, e-mail: digna_np@yahoo.co.uk

2 Minat Utama Gizi dan Kesehatan, Program Studi S2 IImu Kesehatan Masyarakat, Fakultas Kedokteran Universitas Gadjah Mada, JI. Farmako Sekip Utara, Yogyakarta 55281, e-mail: hamam@indosat.net.id

3 Jurusan Gizi, Politeknik Kesehatan Kemenkes Yogyakarta, Jl. Tata Bumi No. 3 Banyuraden, Gamping, Sleman, Yogyakarta
} 


\section{PENDAHULUAN}

Indonesia termasuk negara berkembang dengan tingkat kemiskinan $7,5 \%$ pada tahun 2006. Permasalahan kemiskinan ini berkaitan erat dengan status kesehatan masyarakat Indonesia diantaranya status gizi (1). Kemiskinan berkontribusi terhadap status ketahanan pangan di masyarakat. Hasil penelitian menunjukkan bahwa terdapat hubungan yang bermakna antara pendapatan rumah tangga dengan status ketahanan pangan (2). Terbatasnya ketersediaan pangan dan akses bahan pangan sehat pada rumah tangga miskin menyebabkan masyarakat lebih mengutamakan konsumsi makanan yang murah walaupun kurang bergizi, tinggi lemak, dan memiliki densitas energi yang tinggi. Hal inilah yang menjadi penjelasan memungkinkan bagi keterkaitan antara status ketahanan pangan dengan obesitas secara umum (3).

Hasil Riset Kesehatan Dasar (Riskesdas) 2010 menunjukkan masalah gizi pada penduduk dewasa di atas 18 tahun adalah 12,6\% tergolong kategori kurus dan $21,7 \%$ gabungan kategori berat badan berlebih/overweight dan obesitas. Dengan demikian dapat terlihat bahwa permasalahan gizi pada orang dewasa yang lebih dominan adalah kelebihan berat badan. Secara nasional, prevalensi obesitas pada laki-laki lebih rendah (16,3\%) dibandingkan perempuan (26,9\%). Demikian juga prevalensi obesitas pada laki-laki di Yogyakarta sebesar 8,3\%, lebih rendah dibandingkan perempuan (15,7\%). Data Riskesdas juga menunjukkan bahwa prevalensi berat badan berlebih dan obesitas lebih besar di perkotaan daripada pedesaan (4). Namun, data Riskesdas belum mengategorikan prevalensi obesitas berdasarkan status sosial ekonomi termasuk status kemiskinan.

Aktivitas fisik yang kurang merupakan determinan utama bagi kejadian obesitas pada populasi wanita kulit hitam berpendapatan rendah di Afrika Selatan (5). Aktivitas fisik yang kurang menyebabkan simpanan energi yang semakin berlebih dalam tubuh. Keseimbangan energi positif dapat meningkatkan risiko obesitas (6). Walaupun prevalensi obesitas meningkat secara tajam pada kedua jenis kelamin, tingkatan usia, dan tidak memandang kesukuan, prevalensi obesitas pada populasi yang tidak diuntungkan atau miskin perlu dilihat lebih lanjut (7).

Dewasa ini angka kematian akibat non-communicable disease (NCD) semakin meningkat. Data prevalensi penyakit yang termasuk NCD dalam Riskesdas belum dibagi berdasarkan status sosial-ekonomi sehingga belum dapat diketahui prevalensi NCD pada penduduk miskin. Namun, berdasarkan prevalensi nasional tersebut terlihat bahwa prevalensi salah satu penyakit NCD cukup tinggi yaitu diabetes mellitus (DM). Hasil Riskesdas menunjukkan proporsi penyebab kematian akibat DM pada kelompok usia 45-54 tahun di daerah perkotaan menduduki peringkat ke-2 $(14,7 \%)$ dan di daerah pedesaan DM menduduki peringkat ke-6 (5,8\%) (8). NCD memiliki konsekuensi sosial ekonomi yang serius yaitu berpotensi menyebabkan kemiskinan individu dan rumah tangga serta menghambat pembangunan sosial dan ekonomi. Distribusi dan dampak NCD tidak merata dan cenderung memberikan beban besar yang tidak proporsional terutama bagi negaranegara berpenghasilan rendah dan menengah. Kemiskinan terkait erat dengan NCD dan meningkatnya dampak NCD diperkirakan menghambat inisiatif pengurangan kemiskinan di negara-negara berpenghasilan rendah dan secara langsung pada masyarakat. Pada tingkat rumah tangga, perilaku tidak sehat, status fisik yang buruk, dan tingginya biaya NCD yang terkait perawatan kesehatan mengakibatkan berkurangnya pendapatan rumah tangga. Orang sering terjebak dalam siklus yang berbahaya di mana kemiskinan dan NCD terus memperkuat satu sama lain (9). Berdasarkan berbagai penelitian di atas, penelitian ini ingin menggali faktor risiko obesitas yang spesifik pada ibu rumah tangga miskin yang tinggal di Kota Yogyakarta.

\section{BAHAN DAN METODE}

Penelitian ini merupakan penelitian kasus-kontrol yang berlokasi di dua daerah dengan jumlah penduduk miskin terbesar di Kota Yogyakarta yaitu Kelurahan Bumijo dan Kelurahan Pringgokusuman. Kelurahan Bumijo dan Pringgokusuman merupakan slum area yang terletak di tengah Kota Yogyakarta. Penelitian berlangsung dari bulan Desember 2010 hingga Februari 2011. Kasus yang diambil adalah ibu rumah tangga miskin yang mengalami obesitas. Kontrol adalah ibu rumah tangga miskin yang tidak mengalami obesitas serta berasal dari 1 populasi rukun warga (RW) yang sama dengan kasus. Perbandingan kasus-kontrol adalah 1:1 dan sampel penelitian dipilih menggunakan metode purposive.

Cut off point indeks massa tubuh (IMT) yang digunakan dalam penelitian ini merupakan cut off point IMT untuk populasi benua Asia yaitu lebih besar atau sama dengan $25 \mathrm{~kg} / \mathrm{m}^{2}$ tergolong obesitas (10). Kriteria inklusi kasus yaitu tinggal di lokasi penelitian selama pengambilan data dilakukan, tergolong keluarga miskin berdasarkan data Dinas Sosial Kota Yogyakarta 2009, memiliki IMT lebih dari atau sama dengan $25 \mathrm{~kg} / \mathrm{m}^{2}$, berusia $20-59$ tahun, sudah memiliki anak minimal 1 orang dengan anak terakhir berusia lebih dari 2 tahun, dan bersedia mengikuti penelitian.

Kriteria eksklusi baik kasus maupun kontrol yaitu pindah alamat selama penelitian dilakukan, dirawat inap secara medis atau meninggal selama pengambilan data, menderita penyakit DM atau penyakit lain yang menyebabkan peningkatan berat badan secara tidak wajar, dan ibu yang sedang hamil. Jumlah sampel minimal yang diperlukan berdasarkan rumus besar 
sampel untuk penelitian kasus-kontrol dengan matching pada umur adalah sebesar 69 orang kasus dan 69 orang kontrol (11). Data status ketahanan pangan diperoleh menggunakan kuesioner Radimer/Cornell yang sudah dilakukan uji validitas dan reliabilitas (Chronbach Alpha=0,916; $r$ tabel=0,404). Status ketahanan pangan dinilai menggunakan sistem skor 0 hingga 4 . Skor 0 dikategorikan tahan pangan dan skor 1 sampai dengan 4 dikategorikan rawan pangan. Skor 0 menunjukkan rumah tangga yang tahan pangan, semakin meningkat skor maka derajat kerawanan pangannya semakin meningkat (12).

Data asupan makanan (energi dan lemak) diperoleh menggunakan kuesioner frekuensi makan semi kuantitatif. Penggolongan asupan menjadi berlebih dan cukup berdasarkan Angka Kecukupan Gizi (AKG) yang dianjurkan oleh Widia Karya Pangan dan Gizi (WKPG) 2004 (13). Data tingkat aktivitas fisik diperoleh dengan menggunakan kuesioner International Physical Activity Questionnaires (IPAQ) yang telah dimodifikasi. Penggolongan tingkat aktivitas fisik menjadi rendah dan tinggi menggunakan kriteria IPAQ (14). Uji Chi Square digunakan untuk melihat perbedaan karakteristik dasar subjek, uji Mc.Nemar untuk melihat apakah variabel-variabel yang diteliti merupakan faktor risiko obesitas, dan uji regresi logistik kondisional digunakan untuk menentukan faktor risiko dominan untuk kejadian obesitas pada ibu rumah tangga miskin. Analisis data dilakukan menggunakan perangkat lunak komputer Stata (Stata Corp LP, Texas). Penelitian ini telah mendapatkan persetujuan/kelaikan etik dari Komite Etik Fakultas Kedokteran Universitas Gadjah Mada.

\section{HASIL}

Subjek penelitian sebanyak 140 ibu keluarga miskin yang terdiri dari 70 subjek kelompok kasus (obesitas) dan 70 subjek kelompok kontrol (tidak obesitas). Pada penelitian ini dilakukan matching secara berpasangan antara kelompok kasus dan kontrol berdasarkan umur dengan selisih umur antar kelompok sebesar 5 tahun. Rata-rata umur subjek penelitian pada kelompok kasus adalah 41,53 tahun $(S D \pm 8,44)$ sedangkan rata-rata umur subjek pada kelompok kontrol adalah 41,74 tahun $(S D \pm 8,32)$. Dilihat dari kelompok umur, sebagian besar kasus berada pada kelompok umur 40-49 tahun.

Seluruh subjek penelitian merupakan ibu yang tercantum dalam data Dinas Sosial Kota Yogyakarta sebagai keluarga miskin dan telah diverifikasi menggunakan kuesioner penentuan keluarga miskin pada awal penelitian. Berdasarkan Tabel 1 diketahui bahwa tidak terdapat perbedaan karakteristik antara dua kelompok subjek penelitian. Tabel 2 menunjukkan sebagian besar subjek memiliki status rawan pangan dan proporsi rumah tangga rawan pangan lebih besar pada kelompok kontrol yaitu $91,43 \%$. Proporsi asupan energi dan lemak berlebih
Tabel 1. Karakteristik subjek penelitian

\begin{tabular}{|c|c|c|c|c|}
\hline Variabel & $\begin{array}{l}\text { Kasus } \\
n=70\end{array}$ & $\begin{array}{c}\text { Kontrol } \\
n=70\end{array}$ & $\mathbf{X}^{2}$ & $\mathbf{p}$ \\
\hline \multicolumn{5}{|l|}{ Umur (tahun) } \\
\hline $20-29$ & 6 & 6 & 0,948 & 0,996 \\
\hline $30-39$ & 22 & 22 & & \\
\hline $40-49$ & 29 & 28 & & \\
\hline $50-59$ & 13 & 14 & & \\
\hline \multicolumn{5}{|l|}{ Suku } \\
\hline Jawa & 66 & 69 & 1,867 & 0,172 \\
\hline Sunda & 4 & 1 & & \\
\hline \multicolumn{5}{|l|}{ Pendapatan } \\
\hline$\leq \operatorname{Rp} 600.000$ & 43 & 49 & 1,14 & 0,285 \\
\hline > Rp 600.000 & 27 & 21 & & \\
\hline \multicolumn{5}{|l|}{ Pendidikan ibu } \\
\hline Rendah & 32 & 31 & 0,0289 & 0,865 \\
\hline Menengah & 38 & 39 & & \\
\hline \multicolumn{5}{|l|}{ Pekerjaan ibu } \\
\hline Tidak bekerja/IRT & 34 & 27 & 1,4235 & 0,233 \\
\hline Bekerja & 36 & 43 & & \\
\hline \multicolumn{5}{|c|}{ Jumlah anggota keluarga } \\
\hline$\leq 4$ & 40 & 49 & 2,4983 & 0,114 \\
\hline$>4$ & 30 & 21 & & \\
\hline \multicolumn{5}{|c|}{ Riwayat obesitas keluarga } \\
\hline $\mathrm{Ya}$ & 25 & 23 & 0,1268 & 0,722 \\
\hline Tidak & 45 & 47 & & \\
\hline
\end{tabular}

Keterangan: IRT=ibu rumah tangga

Tabel 2. Status ketahanan pangan, asupan zat gizi, dan aktivitas fisik pada kelompok kasus dan kontol

\begin{tabular}{lcccc}
\hline \multirow{2}{*}{ Variabel } & \multicolumn{2}{c}{ Kasus } & \multicolumn{2}{c}{ Kontrol } \\
\cline { 2 - 5 } & $\mathbf{n}$ & $\mathbf{\%}$ & $\mathbf{n}$ & $\%$ \\
\hline $\begin{array}{l}\text { Status ketahanan pangan } \\
\quad \text { Rawan pangan }\end{array}$ & 61 & 87,14 & 64 & 91,43 \\
$\quad$ Tahan pangan & 9 & 12,86 & 6 & 8,57 \\
$\begin{array}{l}\text { Asupan energi } \\
\quad \text { Berlebih }\end{array}$ & & & & \\
$\quad$ Cukup & 23 & 32,86 & 17 & 24,29 \\
Asupan lemak & 47 & 67,14 & 53 & 75,71 \\
$\quad$ Berlebih & & & & \\
$\quad$ Cukup & 21 & 30 & 20 & 28,57 \\
Aktivitas fisik & 49 & 70 & 50 & 71,43 \\
$\quad$ Rendah & & & & \\
$\quad$ Tinggi & 28 & 40 & 7 & 10 \\
\hline
\end{tabular}

pada kelompok kasus lebih tinggi dibandingkan kelompok kontrol. Tingkat aktivitas fisik yang rendah lebih banyak terdapat pada kelompok kasus (40\%) dibandingkan kelompok kontrol (10\%).

Analisis Mc.Nemar dilakukan untuk melihat hubungan antara keempat variabel dan obesitas dengan melakukan penyetaraan umur. Berdasarkan Tabel 3 diketahui bahwa variabel yang berhubungan bermakna dengan obesitas adalah aktivitas fisik $(p<0,05)$. Hasil uji Mc.Nemar juga menunjukkan bahwa variabel aktivitas fisik memiliki 
Tabel 3. Analisis Mc.Nemar status ketahanan pangan, asupan energi, asupan lemak, dan aktivitas fisik terhadap kejadian obesitas pada ibu rumah tangga miskin

\begin{tabular}{|c|c|c|c|c|c|c|c|}
\hline \multirow{25}{*}{ 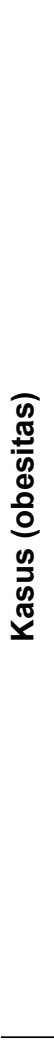 } & \multirow{3}{*}{$\begin{array}{c}\text { Status ketahanan } \\
\text { pangan }\end{array}$} & \multicolumn{2}{|c|}{ Kontrol (tidak obesitas) } & \multirow{3}{*}{ OR } & \multirow{3}{*}{$95 \% \mathrm{Cl}$} & \multirow{3}{*}{$x^{2}$} & \multirow{3}{*}{$\mathbf{p}$} \\
\hline & & \multicolumn{2}{|c|}{ Status ketahanan pangan } & & & & \\
\hline & & Rawan pangan & Tahan pangan & & & & \\
\hline & Rawan pangan & 55 & 6 & 0,67 & $0,19-2,09$ & 0,6 & 0,438 \\
\hline & Tahan pangan & 9 & 0 & & & & \\
\hline & \multirow{3}{*}{ Asupan energi } & \multicolumn{2}{|c|}{ Kontrol (tidak obesitas) } & & & & \\
\hline & & \multicolumn{2}{|c|}{ Asupan energi } & OR & $95 \% \mathrm{Cl}$ & $x^{2}$ & $\mathbf{p}$ \\
\hline & & Berlebih & Cukup & & & & \\
\hline & Berlebih & 5 & 18 & 1,5 & $0,68-3,41$ & 1,2 & 0,273 \\
\hline & Cukup & 12 & 35 & & & & \\
\hline & \multirow{3}{*}{ Asupan lemak } & \multicolumn{2}{|c|}{ Kontrol (tidak obesitas) } & & & & \\
\hline & & \multicolumn{2}{|c|}{ Asupan lemak } & OR & $95 \% \mathrm{Cl}$ & $x^{2}$ & $\mathbf{p}$ \\
\hline & & Berlebih & Cukup & & & & \\
\hline & Berlebih & 8 & $\begin{array}{l}13 \\
37\end{array}$ & 1,1 & $0,45-2,59$ & 0,04 & 0,841 \\
\hline & Cukup & 12 & 37 & & & & \\
\hline & \multirow{3}{*}{ Aktivitas fisik } & \multicolumn{2}{|c|}{ Kontrol (tidak obesitas) } & & & & \\
\hline & & \multicolumn{2}{|c|}{ Aktivitas fisik } & OR & $95 \% \mathrm{Cl}$ & $x^{2}$ & $\mathbf{p}$ \\
\hline & & Rendah & Tinggi & & & & \\
\hline & Rendah & 4 & 24 & 8 & $2,43-41,5$ & 16,33 & 0,0001 \\
\hline & Tinggi & 3 & 39 & & & & \\
\hline & \multirow{3}{*}{ Asupan serat } & \multicolumn{2}{|c|}{ Kontrol (tidak obesitas) } & & & & \\
\hline & & \multicolumn{2}{|c|}{ Asupan serat } & OR & $95 \% \mathrm{Cl}$ & $x^{2}$ & $\mathbf{p}$ \\
\hline & & Rendah & Tinggi & & & & \\
\hline & Rendah & 65 & 1 & 0,33 & $0,006-4,151$ & 1 & 0,31 \\
\hline & Tinggi & 3 & 1 & & & & \\
\hline
\end{tabular}

$\mathrm{OR}=8(95 \% \mathrm{Cl}: 2,43-41,5)$. Hal ini menunjukkan bahwa subjek yang memiliki tingkat aktivitas fisik rendah memiliki kemungkinan 8 kali lebih besar untuk menjadi obesitas dibandingkan subjek yang memiliki tingkat aktivitas fisik tinggi. Hasil uji Mc.Nemar menunjukkan tidak terdapat hubungan yang bermakna antara variabel status ketahanan pangan, asupan energi, dan asupan lemak dengan terjadinya obesitas $(p>0,05)$. Berdasarkan hasil analisis tersebut maka dapat diketahui bahwa variabel aktivitas fisik memberikan kontribusi yang cukup besar bagi terjadinya obesitas, sedangkan asupan energi dan lemak serta status ketahanan pangan tidak menjadi faktor risiko obesitas pada ibu rumah tangga miskin.

Peneliti melakukan analisis korelasi untuk melihat lebih jauh hubungan antara skor aktivitas fisik (Metabolic energy turnover/METs) dengan IMT. Hasil uji korelasi Pearson menunjukkan nilai $r$ sebesar $-0,222(p=0,008)$. Berdasarkan Gambar 1 dapat diketahui bahwa terdapat kecenderungan semakin tinggi skor aktivitas fisik (METs) maka IMT semakin rendah (hubungan negatif).

Analisis stratifikasi dilakukan untuk melihat hubungan asupan energi dan asupan lemak dengan obesitas pada strata aktivitas fisik. Hasil uji stratifikasi menunjukkan bahwa OR pada kelompok yang memiliki tingkat aktivitas fisik rendah berbeda dengan OR pada kelompok yang memiliki tingkat aktivitas fisik tinggi. Dengan demikian, dapat diketahui bahwa tingkat aktivitas fisik merupakan

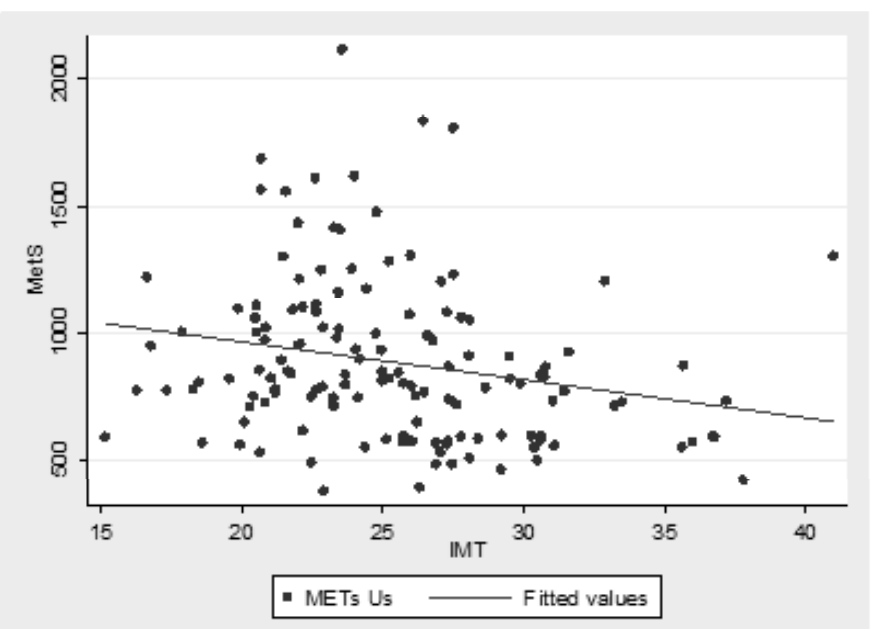

Gambar 1. Diagram kecenderungan hubungan antara skor METs dengan IMT

effect modifier bagi hubungan asupan energi dengan obesitas. Perbedaan crude OR dengan OR hasil uji Maentel Haenzel tidak lebih dari $25 \%$ sehingga dapat diketahui bahwa aktivitas fisik tidak menjadi variabel perancu bagi hubungan antara asupan energi dengan obesitas.

Analisis juga dilakukan untuk melihat hubungan antara asupan serat dengan obesitas (asupan serat diduga sebagai variabel perancu). Sebagian besar subjek penelitian (95,71\%) memiliki asupan serat yang rendah. 
Tabel 4. Faktor yang berpengaruh dominan terhadap kejadian obesitas berdasarkan model regresi logistik kondisional

\begin{tabular}{|c|c|c|c|c|}
\hline Variabel & $\begin{array}{c}\text { Model I } \\
\text { OR } \\
(95 \% \mathrm{Cl})\end{array}$ & $\begin{array}{c}\text { Model II } \\
\text { OR } \\
(95 \% \mathrm{Cl})\end{array}$ & $\begin{array}{c}\text { Model III } \\
\text { OR } \\
(95 \% \mathrm{Cl}) \\
\end{array}$ & $\begin{array}{c}\text { Model IV } \\
\text { OR } \\
(95 \% \mathrm{Cl}) \\
\end{array}$ \\
\hline Status ketahanan pangan & $\begin{array}{c}1,02 \\
(0,32-3,28)\end{array}$ & & & \\
\hline \multicolumn{5}{|l|}{ Rawan pangan } \\
\hline \multicolumn{5}{|l|}{ Tahan pangan } \\
\hline Asupan energi & $\begin{array}{c}2,47 \\
(0,75-8,06)\end{array}$ & $\begin{array}{c}2,46 \\
(0,75-8,05)\end{array}$ & $\begin{array}{c}1,76 \\
(0,77-3,99)\end{array}$ & \\
\hline \multicolumn{5}{|l|}{ Berlebih } \\
\hline \multicolumn{5}{|l|}{ Cukup } \\
\hline Asupan lemak & $\begin{array}{c}0,59 \\
(0,17-2,10)\end{array}$ & $\begin{array}{c}0,59 \\
(0,17-2,10)\end{array}$ & & \\
\hline \multicolumn{5}{|l|}{ Berlebih } \\
\hline \multicolumn{5}{|l|}{ Cukup } \\
\hline Aktivitas fisik & $\begin{array}{c}8,46 \\
(2,48-28,85)\end{array}$ & $\begin{array}{c}8,43 \\
(2,50-28,39)\end{array}$ & $\begin{array}{c}8,51 \\
(2,5-28,7)\end{array}$ & $\begin{array}{c}8 \\
(2,41-26,56)\end{array}$ \\
\hline \multicolumn{5}{|l|}{ Rendah } \\
\hline \multicolumn{5}{|l|}{ Tinggi } \\
\hline $\mathrm{N}$ & 140 & 140 & 140 & 140 \\
\hline $\mathrm{R}^{2}$ & 0,2179 & 0,2179 & 0,2111 & 0,1916 \\
\hline
\end{tabular}

Hasil uji statistic Mc. Nemar menunjukkan asupan serat tidak berhubungan dengan obesitas pada ibu rumah tangga miskin di Kota Yogyakarta $(p>0,05 ; O R=0,33)$.

\section{Faktor yang berpengaruh dominan terhadap terjadinya obesitas}

Untuk mengetahui faktor yang berpengaruh dominan terhadap terjadinya obesitas digunakan model analisis statistik regresi logistik kondisional (conditional logistic regression) (Tabel 4). Model 1 dibangun untuk mengetahui pengaruh aktivitas fisik terhadap obesitas dengan mengikutsertakan variabel asupan energi, asupan lemak, dan status ketahanan pangan. Hasil analisis statistik menunjukkan bahwa terdapat hubungan yang bermakna antara aktivitas fisik dengan obesitas pada ibu rumah tangga miskin dengan mengontrol variabel asupan energi, asupan lemak, dan status ketahanan pangan. Keberadaan variabel-variabel tersebut dapat memprediksi kejadian obesitas pada ibu rumah tangga miskin sebesar $21,79 \%$ sedangkan $78,21 \%$ disebabkan oleh faktor lain yang tidak diteliti dalam penelitian ini.

Model 2 dibangun untuk melihat pengaruh antara variabel aktivitas fisik terhadap kejadian obesitas dengan mengikutsertakan variabel asupan energi dan asupan lemak. Keberadaan variabel ini dapat memprediksi kejadian obesitas pada ibu rumah tangga miskin sebesar $21,79 \%$. Model 3 dibangun untuk melihat pengaruh aktivitas fisik terhadap kejadian obesitas pada ibu rumah tangga miskin dengan mengikutsertakan variabel asupan energi. Keberadaan variabel tersebut dapat memprediksi kejadian obesitas pada ibu rumah tangga miskin sebesar
$21,11 \%$ sedangkan $78,89 \%$ disebabkan oleh faktor lain yang tidak diteliti dalam penelitian ini.

Model 4 dibangun untuk mengetahui pengaruh variabel aktivitas fisik terhadap kejadian obesitas pada ibu rumah tangga miskin tanpa melibatkan variabel luar. Hasil analisis menunjukkan adanya hubungan antara aktivitas fisik dengan kejadian obesitas pada ibu rumah tangga miskin, sehingga dapat diinterpretasikan bahwa aktivitas fisik yang rendah akan meningkatkan risiko obesitas menjadi 8 kali lebih besar pada ibu rumah tangga miskin $(\mathrm{OR}=8 ; 95 \% \mathrm{Cl}: 2,41-26,56)$. Berdasarkan nilai $\mathrm{R}^{2}$, model ini dapat memperkirakan kejadian obesitas pada ibu rumah tangga miskin sebesar $19 \%$.

\section{BAHASAN}

Berdasarkan hasil penelitian ini diketahui bahwa kejadian obesitas lebih banyak terjadi pada rentang umur 45 -49 tahun dengan tingkat pendidikan menengah. Sebagian besar subjek penelitian memiliki pendapatan kurang dari Rp 600.000. Hasil penelitian ini juga menunjukkan bahwa sebagian besar subjek penelitian baik pada kelompok kasus maupun kontrol mempunyai pekerjaan tetap di luar rumah sebagai sumber pendapatan. Status rawan pangan lebih banyak terjadi pada populasi yang tingkat pendidikannya rendah hingga menengah dan memiliki pendapatan yang rendah (15).

Jumlah subjek pada kelompok kasus dengan riwayat obesitas keluarga lebih rendah dibandingkan jumlah subjek yang tidak memiliki riwayat obesitas keluarga. Hal ini dapat mendukung asumsi bahwa timbulnya obesitas lebih 
banyak dipengaruhi oleh faktor lingkungan seperti asupan makanan dan aktivitas fisik. Rata-rata IMT subjek yang mengalami obesitas mencapai $29,1 \mathrm{~kg} / \mathrm{m}^{2}$. Penentuan obesitas pada penelitian ini menggunakan parameter tunggal yaitu indeks massa tubuh (IMT). Beberapa penelitian juga menggunakan parameter yang sama untuk mengukur obesitas (16-18). Cut off point IMT yang digunakan dalam penelitian ini berbeda dengan ketiga penelitian di atas, penelitian ini menggunakan cut off point untuk populasi benua Asia (10).

Hasil penelitian ini menunjukkan bahwa dari 140 subjek yang diteliti, sebanyak 125 orang $(89,29 \%)$ memiliki status rawan pangan. Subjek yang memiliki status rawan pangan sebagian besar terdapat pada kelompok kontrol $(91,43 \%)$ sedangkan subjek dengan status tahan pangan, lebih banyak terdapat pada kelompok kasus $(12,86 \%)$. Hal ini berlawanan dengan penelitian di Amerika yang menyatakan bahwa sebagian besar wanita yang berpendapatan rendah atau miskin yang mengalami obesitas memiliki status rawan pangan. Berdasarkan penelitian tersebut diketahui bahwa wanita yang berpendapatan rendah cenderung untuk membeli makanan dengan densitas energi yang tinggi sehingga memiliki kecenderungan menjadi obesitas. Sebaliknya, penelitian ini menunjukkan bahwa sebagian subjek penelitian yang rawan pangan tidak mengalami obesitas. Dalam penelitian ini, status rawan pangan mencerminkan tidak tersedianya makanan dalam jumlah yang cukup dalam rumah tangga sehingga membatasi jumlah makanan yang akan dikonsumsi anggota keluarga.

Fenomena yang terjadi dalam penelitian ini berlawanan dengan fenomena penelitian di Amerika Serikat yang menjadi acuan dalam penelitian ini (19). Penelitian tersebut memberikan gambaran pola makan di negara maju, di mana konsumsi buah dan sayur tergolong rendah karena harga sayuran dan buah-buahan justru lebih tinggi dibandingkan makanan sumber protein dan lemak. Kondisi sebaliknya terjadi di negara berkembang, di mana sayur dan buah lebih mudah diperoleh dengan harga yang relatif lebih murah jika dibandingkan dengan bahan pangan sumber protein dan lemak.

Hasil penelitian ini justru menunjukkan bahwa status rawan pangan merupakan faktor protektif terhadap obesitas (kelompok tahan pangan sebagai referens). Hasil penelitian ini berlawanan dengan hasil penelitian di Amerika Serikat yaitu penelitian cross-sectional dengan variabel yang sama menemukan bahwa prevalensi obesitas lebih tinggi pada subjek yang rawan pangan (15). Selain itu, status rawan pangan berhubungan positif dengan kejadian overweight pada wanita namun tidak pada pria (16). Penelitian longitudinal dengan desain kohort telah dilakukan di 20 kota besar di Amerika untuk mengidentifikasi lebih lanjut pengaruh dari status ketahanan pangan terhadap peningkatan berat badan ibu. Penelitian tersebut menggunakan data dari "The
Fragile Families and Child Wellbeing Study" (1998 - 2000) yang bertujuan untuk mengetahui pengaruh status ketahanan pangan terhadap peningkatan berat badan ibu yang memiliki balita prasekolah. Hasil penelitian ini menunjukkan bahwa perubahan status ketahanan pangan selama 2 tahun tidak memberikan pengaruh yang bermakna terhadap perubahan berat badan ibu. Dengan demikian, hasil penelitian ini tidak mendukung hubungan kausal antara status ketahanan pangan dengan obesitas (20).

Wanita yang berstatus rawan pangan cenderung untuk mengalami overweight. Namun, hal ini belum didukung bukti yang cukup kuat mengenai hubungan ketahanan pangan dengan peningkatan berat badan. Program dukungan suplementasi gizi yang diberikan pemerintah kemungkinan ikut berperan meningkatkan risiko peningkatan berat badan pada wanita (21). Penelitian di Massachusetts mengidentifikasi bahwa obesitas berhubungan dengan dilaksanakannya program food stamp, namun tidak berhubungan dengan status ketahanan pangan (22). Dalam penelitian ini tidak ditemukan adanya program dukungan gizi yang dilaksanakan di lokasi penelitian ketika penelitian dilakukan.

Asupan energi dan lemak tidak berhubungan bermakna dengan terjadinya obesitas pada ibu rumah tangga miskin. Walaupun hasil analisis menunjukkan tidak terdapat hubungan bermakna antara asupan energi dengan obesitas, namun dengan mempertimbangkan kontribusi yang diberikan terhadap terjadinya obesitas yang mencapai 1,5 kali lebih tinggi maka asupan energi dapat dikatakan merupakan faktor risiko terjadinya obesitas. Asupan lemak tidak berhubungan bermakna dengan obesitas serta kontribusi yang diberikan relatif kecil. Sebuah penelitian di Geneva, Swiss menemukan bahwa asupan lemak kurang dari atau sama dengan $38 \%$ dari total energi belum menjadi faktor risiko terjadinya obesitas $(O R=1)$, asupan lemak lebih dari $38 \%$ dari total energi baru dapat menjadi faktor risiko terjadinya obesitas $(O R=1,4 ; p=0,079)(23)$. Semakin tinggi asupan energi dan lemak maka semakin tinggi risiko peningkatan berat badan (24). Penelitian lain di Belgia menunjukkan asupan energi total, asupan protein, dan asupan lemak lebih tinggi pada subjek yang mengalami obesitas $(p<0,05)$ baik berjenis kelamin laki-laki maupun perempuan (25).

Hasil uji Mc.Nemar memperlihatkan bahwa variabel aktivitas fisik berhubungan bermakna dengan terjadinya obesitas $(\mathrm{OR}=8)$. Berdasarkan hasil analisis, aktivitas fisik diketahui memberikan modifikasi bagi pengaruh asupan energi dan lemak terhadap terjadinya obesitas. Hal ini juga sesuai dengan penelitian di kawasan North West Province, Afrika Selatan yang menunjukkan bahwa asupan energi dan lemak merupakan faktor risiko obesitas, namun variabel yang mempunyai pengaruh lebih besar adalah aktivitas fisik (6). Ketidaksesuaian hasil penelitian ini dengan penelitian sebelumnya dapat juga disebabkan oleh metode pengambilan 
data asupan makan yang digunakan. Asupan energi dan lemak pada penelitian ini dikumpulkan dengan menggunakan kuesioner frekuensi makan semikuantitatif. Terdapat beberapa kelemahan yang memungkinkan terjadinya bias pada saat pengambilan data antara lain metode ini sangat bergantung pada daya ingat subjek. Metode ini memiliki tingkat akurasi yang lebih rendah dibandingkan recall 24 jam, metode pencatatan makan, metode penimbangan makanan, dan metode riwayat diit (26). Under-reporting perlu diperhitungkan ketika menginterpretasikan hasil survei konsumsi makanan. Berbagai penelitian membuktikan bahwa konsumsi makanan tidak dilaporkan dengan benar oleh $20-25 \%$ subjek penelitian terutama pada subjek wanita, individu yang mengalami overweight, dan individu yang sensitif terhadap masalah berat badan (27).

Hasil penelitian menunjukkan bahwa aktivitas fisik yang rendah lebih banyak terdapat pada kelompok kasus (40\%) dibandingkan kelompok kontrol (10\%), sedangkan aktivitas fisik tinggi lebih banyak terdapat pada kelompok kontrol (90\%) dibandingkan kelompok kasus (60\%). Tingkat aktivitas fisik yang rendah berhubungan dengan berbagai faktor. Penelitian di daerah sub urban, Victoria, Australia menemukan bahwa faktor individual, sosial, dan lingkungan berhubungan dengan aktivitas fisik pada wanita yang hidup di wilayah yang tidak menguntungkan secara ekonomi. Penelitian ini secara seksama mengidentifikasi faktor yang berhubungan dengan aktivitas fisik pada waktu luang dan aktivitas fisik berkaitan dengan transportasi. Faktor individual dan sosial berhubungan bermakna dengan aktivitas fisik pada waktu luang sedangkan dukungan sosial, maksud atau tujuan, kesenangan, adanya lingkungan yang mendukung kebiasaan berjalan kaki, dan kemauan pribadi berhubungan bermakna dengan aktivitas fisik yang berkaitan dengan transportasi (28). Beberapa penelitian mengemukakan bahwa individu yang tinggal di daerah yang tidak menguntungkan dari segi ekonomi menciptakan peluang peningkatan risiko fisik menjadi tidak aktif (29-31).

Asupan serat yang diduga sebagai variabel perancu diketahui tidak berhubungan dengan obesitas. Hal ini disebabkan sebagian besar subjek penelitian pada kelompok kasus maupun kontrol sama-sama memiliki tingkat asupan serat yang rendah (terdapat 65 pasang kasus-kontrol yang sama-sama memiliki asupan serat rendah). Hasil penelitian ini berlawanan dengan hasil penelitian yang menyatakan bahwa rendahnya asupan serat dapat berkontribusi terhadap terjadinya obesitas (32). Perbedaan hasil penelitian ini disebabkan oleh subjek pada penelitian tersebut memiliki tingkat asupan serat yang tidak terdistribusi hanya pada satu sisi seperti pada penelitian ini di mana sebagian besar subjek memiliki tingkat asupan serat yang rendah. Sebanyak $95,71 \%$ dari keseluruhan subjek penelitian ini memiliki tingkat asupan serat rendah disebabkan oleh rendahnya konsumsi sayur dan buah yang merupakan bahan makanan sumber serat.
Studi kualitatif yang dilakukan di Minnesota, Amerika Serikat menunjukkan bahwa wanita berpendapatan rendah akan kesulitan untuk menjangkau makanan sehat (buah dan sayur). Lebih jauh lagi, rendahnya pengetahuan tentang gizi pada keluarga miskin berhubungan dengan cara pengolahan makanan yang tidak benar sehingga menghasilkan makanan yang kurang sehat (19).

Berdasarkan hasil uji multivariat, faktor risiko yang berpengaruh dominan terhadap kejadian obesitas pada ibu rumah tangga miskin adalah aktivitas fisik. Hal ini sejalan dengan hasil penelitian lain yang menemukan bahwa aktivitas fisik merupakan determinan utama bagi kejadian obesitas pada wanita kulit hitam di Afrika Selatan. Wanita yang memiliki tingkat aktivitas fisik yang tinggi memiliki kemungkinan lebih kecil untuk menjadi obes $(O R=0,38)$ (6). Hasil uji multivariat menunjukkan bahwa variabel aktivitas fisik dapat memprediksi kejadian obesitas pada ibu rumah tangga miskin sebesar $19 \%$ tanpa melibatkan variabel yang lain.

Subjek penelitian yang merupakan ibu rumah tangga miskin yang tinggal di daerah tidak menguntungkan dari segi ekonomi, rentan terhadap kemungkinan fisik menjadi tidak aktif, padahal rendahnya tingkat aktivitas fisik tersebut terbukti meningkatkan risiko obesitas. Obesitas memberikan dampak yang besar bagi kualitas hidup seseorang karena obesitas dapat menjadi penyebab tidak langsung timbulnya beberapa penyakit (DM, hipertensi, gangguan saluran pernapasan, gangguan persendian), meningkatnya risiko premature death, dan mengurangi produktivitas kerja seseorang sehingga berpotensi mengurangi pendapatan. Pada subjek penelitian yang termasuk rumah tangga miskin, hal tersebut dapat menciptakan lingkaran setan permasalahan kemiskinan (33). Dengan diketahuinya faktor aktivitas fisik berhubungan bermakna dengan obesitas maka dapat dilakukan upaya intervensi untuk mengurangi prevalensi obesitas pada masyarakat miskin.

\section{SIMPULAN DAN SARAN}

Faktor risiko dominan terhadap terjadinya obesitas pada ibu rumah tangga miskin di Kota Yogyakarta adalah rendahnya tingkat aktivitas fisik. Asupan energi juga memberikan kontribusi yang cukup besar terhadap kejadian obesitas walaupun tidak menunjukkan hubungan yang bermakna. Sedangkan asupan lemak memberikan kontribusi yang sangat kecil terhadap terjadinya obesitas dengan modifikasi pada aktivitas fisik. Status ketahanan pangan belum menjadi faktor risiko terjadinya obesitas pada ibu rumah tangga miskin di Kota Yogyakarta.

Pemberian edukasi melalui organisasi Pembinaan Kesejahteraan Keluarga (PKK) maupun kader posyandu mengenai cara memilih menu yang bergizi seimbang perlu dilakukan sehingga ibu yang termasuk dalam keluarga 
miskin tetap dapat memenuhi kebutuhan gizinya dengan baik dan benar, terutama berkaitan dengan pengaturan makan rendah kalori bagi ibu yang obesitas. Edukasi dan program olahraga di masing-masing lingkungan perlu direvitalisasi dengan tujuan untuk meningkatkan aktivitas fisik ibu-ibu yang mengalami obesitas. Sehingga, walaupun ibu-ibu tersebut mengonsumsi energi tinggi diharapkan akan terjadi penurunan berat badan hingga mencapai berat badan normal jika diiringi aktivitas fisik yang cukup.

\section{RUJUKAN}

1. Stalker P. Let's speak out for MDGs; achieving the millenium development goals in Indonesia 2007. Jakarta: Bappenas and UNDP, MDGs Thematic Working Group; 2007.

2. Oh SY, Hong MJ. Food insecurity is associated with dietary intake and body size of Korean children from low-income families in urban areas. Eur J Clin Nutr 2007;57(12):1598-604.

3. Shariff ZM, Khor GL. Obesity and household food insecurity: evidence from a sample of rural households in Malaysia. Eur J Clin Nutr 2005;59(9):1049-58.

4. Badan Penelitian Pengembangan Kesehatan. Laporan hasil riset kesehatan dasar (Riskesdas) Indonesia tahun 2010. Jakarta: Departemen Kesehatan Republik Indonesia; 2011.

5. Kruger HS, Venter CS, Vorster HH, Margetts BM. Physical inactivity is the major determinant of obesity in black women in the North West province, South Africa: the THUSA study. Nutrition 2002;18(5):422-7.

6. Rennie $\mathrm{KL}$, Johnson $\mathrm{L}$, Jebb SA. Behavioural determinants of obesity. Best Pract Res Clin Endocrinol Metab 2005;19(3):343-58.

7. Drewnowski A, Darmon N. The economics of obesity: dietary energy density and energy cost. Am J Clin Nutr 2005;82(1):265S-73.

8. Badan Penelitian Pengembangan Kesehatan. Laporan hasil riset kesehatan dasar (Riskesdas) Indonesia tahun 2007. Jakarta: Departemen Kesehatan Republik Indonesia; 2008

9. Alwan A, Armstrong T, Bettcher D, Branca F, Chisholm D, Ezzati M, Garfield R, MacLean D, Mathers C, Mendis S, Poznyak V, Riley L, Kwok CT, Wild C. WHO global status report on noncommunicable diseases 2010. Geneva: World Health Organization Press; 2011.

10. Inoue S, Zimmet P, Caterson I, Chunming C, Ikeda Y, Khalid AK, Kim YS, Basset J. The Asia-Pacific perspective: redefining obesity and its treatment. Australia: Health Communications Australia Pty Limited on behalf of the Steering Committee (International Diabetes Institute, WPRO, WHO, the International Association for Study of Obesity and the International Obesity Task Force/ IOTF); 2000.
11. Madiyono B, Moeslichan S, Sastroasmoro S, Budiman I, Purwanto SH. Perkiraan besar sampel. Dalam: Dasar-dasar metodologi penelitian klinis. Sastroasmoro S, Ismael S, editor. Jakarta: Sagung Seto; 2002.

12. Studdert LJ, Frongillo EA, Valois P. Household food insecurity was prevalent in Java during Indonesia's economic crisis. J Nutr 2001;131(10):2685-91.

13. Almatsier S. Prinsip dasar ilmu gizi. Jakarta: Gramedia Pustaka Utama; 2010.

14. Guidelines for Data Processing and Analysis of the International Physical Activity Questionnaire (IPAQ). [series online] 2005 [cited 2010 Jun 7]. Available from: URL: http.//www.ipaq.ki.se

15. Mello JA, Gans KM, Risica PM, Kirtania U, Strolla LO, Fournier L. How is food insecurity associated with dietary behaviours? an analysis with low-income, ethnically diverse participants in a nutrition intervention study. J Am Diet Assoc 2010;110(12):1906-11.

16. Adams EJ, Grummer-Strawn L, Chavez G. Food insecurity is associated with increased risk of obesity in California women. J Nutr 2003;133(4):1070-4.

17. Townsend MS, Peerson J, Love B, Achterberg C, Murphy SP. Food insecurity is positively related to overweight in women. J Nutr 2001;131(6):1738-45.

18. Gulliford MC, Mahabir D, Rocke B. Food insecurity, food choices, and body mass index in adults: nutrition transition in Trinidad and Tobago. Int $\mathrm{J}$ Epidemiol 2003;32(4):508-16.

19. Dammann KW, Smith $\mathrm{C}$. Factors affecting low-income women's food choices and the perceived impact of dietary intake and socio-economic status on their health and weight. J Nutr Educ Behav 2009;41(4):242-53.

20. Whitaker RC, Sarin A. Change in food security status and change in weight are not associated in urban women with preschool children. J Nutr 2007;137:2134-9.

21. Larson NI, Story MT. Food insecurity and weight status among U.S. children and families, a review of the literature. Am J Prev Med 2011;40(2):166-73.

22. Webb AL, Schiff A, Currivan D, Villamor E. Food stamp program participation but not food insecurity is associated with higher adult BMI in Massachusetts residents living in low-income neighbourhoods. Public Health Nutr 2008;11(12):1248-55.

23. Bernstein MS, Costanza MC, Morabia A. Association of physical activity intensity levels with overweight and obesity in a population-based sample of adults. Prev Med 2004;38(1):94-104.

24. Klesges RC, Klesges LM, Haddock CK, Eck LH. A longitudinal analysis of the impact of dietary intake and physical activity on weight change in adults. Am J Clin Nutr 1992;55(4):818-22.

25. Duvigneaud N, Wijndaele K, Matton L, Philippaerts R, Lefevre J, Thomis M, Delecluse C, Duquet W. Dietary 
factor associated with obesity indicators and level of sports participation in Flemish adults: a cross-sectional study. Nutr J 2007;6:26.

26. Gibson RS. Principles of nutritional assessment. New York: Oxford University Press, Inc; 2005.

27. Sherwood NE, Story M, Neumark-Sztainer D. Chapter 34: behavioral risk factors for obesity: diet and physical activity. In: Nutrition in the prevention and treatment of disease. Minnesota: Academic Press; 2001.

28. Cleland V, Ball K, Hume C, Timperio A, King AC, Crawford D. Individual, social and environmental correlates of physical activity among women living in socioeconomically disadvantaged neighbourhoods. Soc Sci Med 2010;70(12):2011-8.

29. Gidlow C, Johnston LH, Crone D, Ellis N, James D. A systematic review of the relationship between socio-economic position and physical activity. Health Education Journal 2006;65(4):338-67.

30. Giles-Corti B, Donovan RJ. Socioeconomic status differences in recreational physical activity levels and real and perceived access to a supportive physical environment. Prev Med 2002;35(6):601-11.

31. King T, Kavanagh AM, Jolley D, Turrell G, Crawford D. Weight and place: a multilevel cross-sectional survey of area-level social disadvantage and overweight/obesity in Australia. Int J Obes 2006;30(2):281-7.

32. Howart NC, Huang TTK, Roberts SB, Mc.Crory MA. Dietary fiber and fat are associated with excess weight in young and middle-aged US adults. J Am Diet Assoc 2005;105(9):1365-72.

33. Formiguera $X$, Canton $A$. Obesity: epidemiology and clinical aspects. Best Pract Res Clin Gastroenterol 2004;18(6):1125-46. 